\title{
PERITONSILLOLITH
}

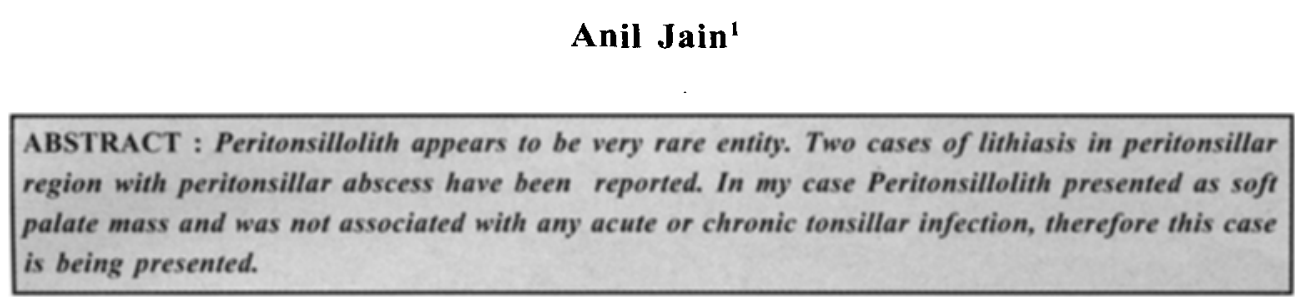

Key Word : Tonsillolith, Peritonsillolith

\section{REVIEW OF LITERATURE :}

Few large tonsillolith wherever reported in literature are present on medial surface of tonsil. Cooper MM and Steinberg JJ in 1982 reported a large tonsillar calculus in a 77 year old women with history of chronic oral infection and multiple episodes of pneumonia. Heppt W., Schmidt ST reported a tonsillolith of $7 \mathrm{gm}$. in 77 year old patient simulating a tumor of the oropharynx. Wedrychowicz B. and Pogorzelski A. reported a case of a big stone of palatine tonsil in 1993.

Two cases of large lithiasis in peritonsillar region associated with peritonsillar abscess were also reported by Kimure $\mathrm{H}$, Ohashi N. in 1993 and Modrzynski M, Wrobel B. in Nov. 2001. Here a diagnosis of peritonsillar abscess was first made and the stone was removed after drainage of the abscess.

In available literature "Peritonsillolith" was first coined by Samant HC, and Gupta OP in 1975. They have speculated about the cause of peritonsillolith. As lithiasis in other parts of body like Gall bladder, Kidney, Salivary gland, the peritonsilloliths most likely form as result of incomplete evacuation of pus, and dead bacteria with pus cells providing the nidus for the formation of stone.

\section{CASE REPORT}

A 40 year old female presented with complaint of swelling in the mouth on left side and mild odynophagia since 2 years. Swelling was increasing gradually in size since one year. There was no history of recurrent sore throat, fever or dysphagia.

Clinical examination revealed a smooth bulge over upper part of left anterior pillar and adjoining soft palate measuring vertically about $3.5 \mathrm{~cm}$ and horizontally about
$2.5 \mathrm{~cm}$.On palpation swelling was mildly tender and stony hard and slightly mobile.

Overlying mucosa was smooth and slightly congested. Tonsil was pushed downwards. Plain Xray of neck lateral view revealed a well defined circular radio opaque shadow just above the angle of the mandible (Fig.I). Fine needle aspiration was tried for cytology but the needle could not penetrate the swelling.

Under general anaesthesia a $3 \mathrm{~cm}$. long horizontally curved incision was made over mid-part of swelling. Mucosa was cut and muscles of soft palate were separated from swelling and calculus of $28 \times 20 \mathrm{~mm}$ size was easily delivered from Peritonsillar region. (Fig.II). Wound was stiched in a single layer. Post-op recovery was uneventful. Edema

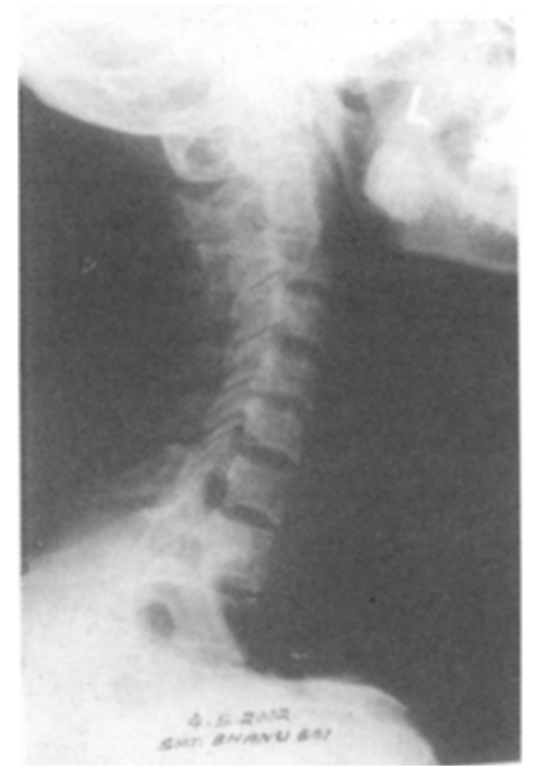

Fig. I : Plain X-ray of neck showing stone 


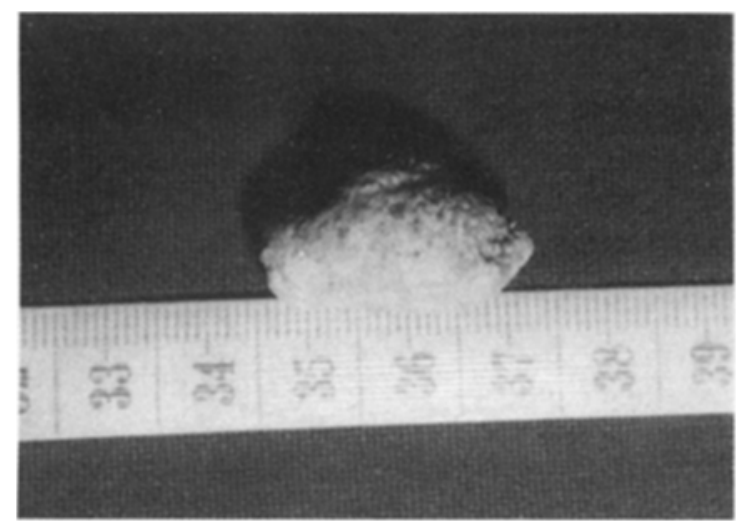

Fig. II : Peritonsillolith after removal

and congestion of soft palate and anterior pillar was settled within a few days.

\section{DISCUSSION}

Usually calculus in palatine tonsil present on its medial surface and their sizes vary from few $\mathrm{mm}$ to a $\mathrm{cm}$. Peritonsillolith is a very rare entity and rarer in its presentation like swelling on soft palate. In available literature, two cases of peritonsillolith were reported with peritonsillar abscess but in this case there was no symptom and sign suggestive of tonsillar infection, so one may confuse with soft palate tumor. In our case, probably stone started developing in supra tonsillar crypt and gradually increased in size and pushed into the upper part of peritonsillar region. Once it is diagnosed on Xray and soft palate pathology is ruled out, it can be easily removed.

\section{REFERENCES}

1. Heppt. W Schmidt ST. Amstutz GC Maier H., Tonsillolith (1989): Clinical picture and minealogic analysis, HNO 37(10) : 438-9.

2. Samant HC., Gupta OP. Peritonsillolith, Oral Surgery, Oral Medicine, Oral Pathology. 40(1).

3. Kimura H. Ohashi N. Nakagawa H. Asai M. Koizumi F., (1993): Large tonsillolith mimicking peritonsillar abscess : a case report , Auris, Nausus, Larynx, 20(1): 73-8.

4. Wedrychowicz B Pogorzelski A,.(1993) : A case of palatine tonsil stone (Polish), Otolaryngologia Polska 47(6):569-73.

5. Modrzynski M. Wrobel B. Zawisza E:, (2001): Giant tonsillolith simulating peritonsillar abscess (Polish) Polski Merkuriusz 11(65): $432-3$.

\section{Address for Correspondence :}

Dr. Anil Jain

Qt. No.-C/69, Sect - 1,

Devendra Nagar, Raipur (C.G.)

Pin : 492001 